SISTEMA
ELETRÔNICO
DE REVISTAS
SER I UFPR

\title{
The impact of decentralization policies: the environmental performance applied to municipalities of the Amazon
}

\section{O impacto de políticas descentralizadas: o desempenho ambiental aplicado a municípios da Amazônia}

\author{
Benedito Evandro Barros da SILVA ${ }^{1,2^{*}}$, Claudia AZEVEDO-RAMOS ${ }^{3}$, Hilder André Bezerra FARIAS ${ }^{4}$ \\ ${ }^{1}$ Programa de Pós-Graduação em Desenvolvimento Sustentável dos Trópicos Úmidos, Universidade Federal do Pará (UFPA), Belém, PA, Brasil. \\ ${ }^{2}$ Secretaria de Estado de Meio Ambiente do Pará (SEMAS/PA), Belém, PA, Brasil. \\ ${ }^{3}$ Núcleo de Altos Estudos da Amazônia (NAEA), Universidade Federal do Pará (UFPA), Belém, PA, Brasil. \\ ${ }^{4}$ Departamento de Economia, Universidade Federal do Pará (UFPA), Belém, PA, Brasil. \\ ${ }^{*}$ E-mail of contact: evandroourem@yahoo.com.br
}

Article received on September 22, 2018, final version accepted on May 23, 2019.

ABSTRACT: The historical environmental problems in the Amazon urge greater governance and transparency at the municipal level. The decentralizing of municipal environmental management (MEM) is an ongoing process in the Brazilian Amazonbut a monitoring mechanism is missing. We used an index (iMEM) derived by factorial analysis to rank the environmental management performance of 143 municipalities in Pará state at the beginning of the decentralizing process (2009) and six years after that (2015). Multiple regression analysis indicated that iMEM was positively affected by factors such as population, communication and protected areas in the municipalities and negatively affected by rural credit, GDP and property registration program. Decentralizing measures seem to be more politically than environmentally effective since only $21.7 \%$ of 143 municipalities were classified as having good environmental management in 2015. Pará's poorly performing municipalities in both periods illustrate regions where unsustainable and misguided national policies were fostered in the 70s. The monitoring of the decentralization progress and synergic policies is crucial for the effectiveness of the policy in the Amazon.

Keywords: Amazon; indicators; municipal environmental management; Pará; Brazil.

RESUMO: Os problemas ambientais históricos na Amazônia exigem maior governança e transparência no nível municipal. A descentralização da gestão ambiental municipal (MEM, acrônimo em inglês) é um processo em andamento na Amazônia brasileira, embora esteja faltando um mecanismo de monitoramento. Nós utilizamos um índice 
(iMEM) derivado de análise fatorial para classificar o desempenho da gestão ambiental de 143 municípios do estado do Pará no início do processo de descentralização (2009) e seis anos depois (2015). Análises de regressão múltipla indicaram, ainda, que o iMEM foi positivamente afetado por fatores como população, comunicação e áreas protegidas nos municípios e negativamente afetados pelo crédito rural, PIB e programa de registro de imóveis. As medidas descentralizadoras parecem ser mais política do que ambientalmente eficazes uma vez que apenas $21,7 \%$ dos 143 municípios foram classificados como tendo boa gestão ambiental em 2015. Os municípios com desempenho insatisfatório do Pará em ambos os períodos ilustram regiões onde políticas nacionais insustentáveis e equivocadas foram fomentadas na década de 70 . O monitoramento do progresso da descentralização e das políticas sinérgicas é, portanto, crucial para a eficácia da política na Amazônia.

Palavras-chave: Amazônia; Brasil; gestão ambiental municipal; governança; monitoramento.

\section{Introduction}

Many environmental problems have local origins (Mori \& Christodoulou, 2012), especially at the municipal level. However, when power structures are highly centralized at the federal or state levels, municipalities have few tools to contribute to solving environmental problems that first occur within their territory. Power decentralization is, therefore, indicated as a mechanism that may overcome several management and political problems (Gibson \& Lehoucq, 2003; Schmitt \& Scardua, 2015). In Latin America, where centralized power has predominated (Andersson et al, 2006; Andersson \& Laerhoven, 2007; Larsen, 2011; De Lima \& Buszynski, 2011), political-administrative decentralization is still an ongoing process (Falleti, 2010).

In tropical countries, decentralization reforms may also contribute to environmental governance at the municipal level, especially in rural frontiers where extractive industries, large infrastructure works and land conflicts abound. That may be achieved by empowering local communities, implementing the appropriate legal framework and strengthening institutional structures (Larsen, 2011; De Lima \& Buszynski, 2011). By means of decentrali- zation, municipalities are expected to assume tasks previously centralized at the state or federal level. Nevertheless, despite the role of municipalities in contributing to local environmental governance, little attention has been paid to the challenge involved and to the performance of municipal environment management. Indeed, studies using a large sample of municipalities to test their performance after decentralization processes remains almost absent from the literature.

In Brazil, the pressure for decentralization of environmental management to local governments has intensified because of the growing demand for natural resources, the need for environmental protection and the national and international pressure to reduce deforestation in the Amazon (Nepstad et al., 2014; Zarin et al., 2016). The rationale of environmental decentralization resides in the belief that local governments are more familiar with both local-society needs and environmental characteristics and, therefore, can design more appropriate policies (Anderson et al., 2006). The institutionalization of the environmental decentralization process in Brazil was strengthened by a diverse legal framework (e.g. National Environment Policy act of 1981; the new Federal Constitution of 1988; and Resolution 
277/97 of the National Environment Council CONAMA); and public policies (e.g. Action Plan for Prevention and Control of Deforestation in the Amazon) (Viana et al., 2016). Currently, municipalities share the responsibility for command \& control processes and environmental management with federal and state governments. However, due to political interferences and historical structural and personnel fragilities at local level, the ability of municipalities to effectively carry out environmental management is challenging, not only in Brazil (Schmitt \& Scardua, 2015) but in several other countries in Latin America (Andersson et al., 2006, Andersson \& Laerhoven, 2007, Gabaldón, 2009; Larsen, 2011) and the developing world (Coleman \& Fleischman, 2012; Persha \& Andersson, 2014).

The Amazon is an area of global importance and concerns. Issues, such as climate changes, forest conservation, biodiversity and water conservation have been sources of international debates, investment and search for solutions for decades. The main causes of the Brazilian Amazon deforestation are related to changes in land use associated with livestock, extensive agriculture and exploitation of natural resources (Kaimowitz et al., 2004; Nepstad et al., 2014; Moutinho et al., 2016). In this scenario, forest governance in this region became the main goal of the central government and, therefore, environmental decentralization policies have been introduced with the aim of reducing deforestation and reinforcing a sustainably-based economy (De Lima \& Buszynski, 2011). Ultimately, the choice and manner of developing economic activities in the Amazon municipalities will lead to forest conservation or to forest conversion to other types of land use. As the municipalities also act as licensors and regulators of economic activities, they are co-responsible for the local environmental consequences. Nevertheless, standard tools for assessing their effectiveness in environmental management are still lacking.

In the Brazilian Amazon, the state of Pará has historically been one of the champions of deforestation (INPE, 2017a). In order to reverse this scenario, Pará has, in recent years, boosted environmental decentralization using different public policies that subsidize the structuring and strengthening of municipal environmental systems. Between 2009 and 2015, the number of municipalities with decentralized management increased from 10 to 69 (of a total of 144), motivated mainly by public policies of deforestation reduction (Silva \& Azevedo-Ramos, 2016). According to the state environmental agency, 115 municipalities had decentralized environmental management in 2017. Pará, therefore, provides an interesting case study because it is at the same time one of the states with the greatest environmental problems and the one demonstrating greatest willingness for decentralizing the environmental management in the Brazilian Amazon (Silva \& Azevedo-Ramos, 2016). As Pará's municipalities are mostly poor and located in politically marginal areas, implementing their new tasks can be challenging. That increases the importance of applying monitoring mechanisms to evaluate the progress of municipal environmental management (MEM) and to subsidize the planning of actions. The lessons learned from this experience may work as a reference point for other states or countries that are on the same path.

In this context, the aim of this study is to analyze the environmental management performance of 143 municipalities in the state of Pará at the beginning of the political-administrative de- 
centralizing process (2009) and six years after that (2015). The evaluation was performed by creating a municipal environmental management index (iMEM) and ranking the municipalities according to their performance for each year. Then, potential variables that may influence the performance were identified. Finally, the implications of the findings were discussed under the context of the decentralization process.

\section{Materials and methods}

Environmental management was evaluated in 143 municipalities of Pará, excluding one recently created municipality (Mojuí dos Campos), for which data are still limited (IBGE, 2017a). MEM was evaluated in two periods: 2009 (beginning of the decentralization process) and 2015 (the most recent available year in the time series data).

The starting point for the initial selection of variables to create an index of performance (iMEM) was the open-access dataset of sustainable development indicators published by the National Institute of Geography and Statistics (IBGE, 2015). An initial set of 20 (out of 67) variables most closely related to the environmental issues of the Brazilian Amazon described in the literature was selected by the authors. Then, the variables were validated by experts and public managers using an adaptation of the content validity method (Nicole \& Tronchin, 2011; Bomfim, 2014). An electronic questionnaire containing descriptions of the variables, their data sources and scoring options ranging from 0 (do not use) to 5 (very good) was distributed to 63 evaluators with proven experience in econometrics and public management. The questionnaires had a return rate of $31.7 \%(n=20)$. A variable from the list was validated if the average score was $>3$. Qualitative observations from the evaluators were also considered to include variables not originally present on the list. Variables selected by the experts were then divided into two groups by the authors: performance and input variables. The rationale behind this classification was that performance variables indicate the result of the management process (e.g., deforestation control; land-use change; quality of life). In turn, input variables indicate the resources or conditions to do the management (e.g., infrastructure; budget; personnel). Therefore, performance variables were used to create the iMEM (see section 2.1), which ultimately measures the result of the management. The input variables were used in multiple regression analyses as potential explanatory variables that may describe the relationship with iMEM (section 2.2). Eleven variables mainly related to environmental management performance (Table 1) and 12 input variables (Table 2) were identified.

Available data from 2009 and 2015 were used for each variable. In the case of missing data, the annual value consisted of the average of the previous and the following years. Data were sourced from governmental institutions that had the best quality data available at the municipal level, regarding attributes such as validity, reliability, comparability, simplicity, sensitivity and data availability (Singh et al., 2009). 
TABLE 1 - Variables and data sources used for the environmental-management assessment of 143 municipalities in Pará, Brazil, in 2009 and 2015.

\section{VARIABLE NAME}

DESCRIPTION
JUSTIFICATION
DATA SOURCES

(year used in the dataset)
Percentage of municipal land cover identified as exposed soil, degraded pasture, mined area and deforested area per municipality relative to municipality area (2009 and 2013).

Cattle

(heads $/ \mathrm{km}^{2}$ )

Accumulated deforestation

$\left(\mathrm{km}^{2}\right)$

Deforestation increase

$\left(\mathrm{km}^{2}\right)$

Heat sources (number of sources/ $\mathrm{km}^{2}$ )

Quality of life index (FIRJAN)

Crops

$\left(\mathrm{km}^{2}\right)$

Pasture

$\left(\mathrm{km}^{2}\right)$
Number of cattle relative to municipality area (2009 and 2015).

Mean gross accumulated deforestation value over three years for 2009 (2007, 2008 and 2009) and 2015 (2013, 2014, 2015) relative to municipality area.

Mean annual recent deforestation for 2009 (2007, 2008, 2009) and 2015 (2013, 2014, 2015) relative to municipality area.

Annual occurrence of forest heat sources relative to municipality area.

Value of the FIRJAN index (Employment, Income, Education and Health) relative to the population of the municipality in the

Planted area of permanent + temporary crops relative to municipality area.

Mean pasture area (pasture with exposed soil, "clean" pasture, "dirty" pasture) relative to municipality area. year studied (2009 and 2015).
Represents the environmental liabilities of each municipality, which will require more management capacity.

Livestock expansion is related to a higher demand for deforested areas and increasing land use disputes.*

IBGE, 2017a (2009 and 2015)

Deforestation damages biodiversity and forest-related ecological services, with consequences for human populations.

Deforestation damages biodiversity and forest-related ecological services, with consequences for human populations.

Indicator of the advance of agricultural and livestock activities and of anthropogenic areas over native vegetation areas provided that it is associated with other indicators.*

Used as an aggregate measure of the quality of life of the population. The FIRJAN index was selected because data were available for the study years.

SISTEMA FIRJAN,

Shows the variations in pressure on the land and resulting increase in land use disputes. Permanent and temporary crops are related to a higher demand for deforested areas.*

Shows the variations in pressure on the land and resulting increase in land use disputes. Livestock is associated with deforestation in the Amazon. 2015 (2009 and 2015)

IBGE, 2017a (2009 and 2015)

FAPESPA, 2015

(2009 and 2015)

INPE, 2017c (2008 and 2014) 
Pasture regeneration $\left(\mathrm{km}^{2}\right)$

Secondary vegetation $\left(\mathrm{km}^{2}\right)$

Infant mortality rate (\%)
Area of pasture regeneration relative to municipality area.

Area of secondary vegetation relative to municipality area.

Risk of death of live-born infants during their first year of life relative to the population of the municipality in the study year.
An indicator of plant regeneration in pasture areas. Normally associated with abandoned pastures.

An indicator of plant regeneration.

Contributes to the evaluation of levels of health, environmental/sanitary infrastructure and socio-economic development of the population.* (also used as a proxy for respiratory and parasitic diseases and sanitation).
INPE, 2017c (2008 and 2014)

INPE, 2017c (2008 and 2014)

MS, 2015 (2009 and 2015)

* As defined by IBGE (2015).

TABLE 2 - Independent variables used in the multiple regression analyses.

\section{VARIABLE NAME DESCRIPTION JUSTIFICATION}

DATA SOURCES (year used in the dataset)

FAPESPA, 2015

(2009 and 2015) and providing environmental goods and services to local communities.*

More access to these services reduces transportation needs, which can favorably affect the environment and IBGE, 2017a (2009 improve access to environmental information.* and 2015)

The more widespread internet access is, the higher the possibility that society is better informed about sustainable development issues in the municipalities.* Facilitates environmental management by means of information and use of systems.

IBGE, 2017a (2009 and 2015) the resident population of each municipality.

Areas of properties registered in relation to each registrable area

Rural environmental cadaster $(\%)$ in the municipality expressed as a percentage in relation to the population.

Public electronic registration of declaratory and mandatory nature, applied to all rural properties of the country for environmental regulation, facilitating the monitoring of legal compliance.

SEMAS, 2017b

(2009 and 2015)

Identifies the potential of land use and occupation in the municipality; directly related to changes in vegeta-
BACEN, (2009 and 2013)
Value of financed credit per population)

\author{
municipality.
}

tion, soils, water resources and others.

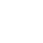


Energy (kWh/population)

Population density (number of people/ $\mathrm{km}^{2}$ )

Municipal environmental management - MEM

State tax (R \$population)

Number of employees ([number of employees/ total population]*100)

Population growth rate $(\%)$

Municipal gross domestic product (GDPm) per capita (R\$)
Annual final energy consumption per inhabitant.

The production, consumption and resulting subpro-

Number of inhabitants in relation to the area of each municipality.

Capacity of the municipality to perform MEM (yes or no).

Value of tax on the circulation of goods and services transferred from the state to the municipality in relation to its total population.

Total number of municipal public employees in relation to the total population, expressed as a percentage.

Annual population growth rate of the municipality.

The monetary sum of all final goods and services produced in a given municipality in relation to its population during a certain period ducts of energy supply exert pressure on the environment and natural resources.*

The number of people represents the presence of an-

thropogenic actions in a territory, with impacts on the land, water resources and local biodiversity.*

Indicates if the municipality is empowered to perform municipal environmental management according to regulations (Complementary Law 140/11 and COEMA Resolution 120/2015).
Represents tax proceeds obtained from the circulation of goods; it may be a source of resources to be invested in municipal environmental management.
FAPESPA, 2015

(2009 and 2015)

IBGE, 2017a (2009

and 2015)

SEMAS, 2017a

(2017)

FAPESPA, 2015

(2009 and 2015)

IBGE, 2017b (2009

and 2015) may provide better services and municipal environmental management.

The dynamics of demographic growth allow the sizing of demands, such as access to healthcare and sanitation services and basic equipment, education, social infrastructure, and employment.*

IBGE, 2017c (2009

and 2015)

The economic development of a municipality is related to economic activities that can generate pressure on natural resources and the environment.
IBGE, 2017a (2009 and 2014)

* As defined by IBGE (2015).

\subsection{Data analysis and iMEM}

The 11 selected performance variables (Table 1) were standardized to reduce data variation and amplitude to allow comparison while maintaining the relative importance of the measurement. Variable correlation was evaluated at the 5\% significance level. The final determination of the variables and their weights to create the iMEM was undertaken using factor analysis - FA (Hair et al., 2006). A similar methodology was applied when analyzing the social dimension of the Amazon municipalities (IPS Amazônia, 2014). FA technique allows initial identification of the isolated dimensions of the data 
structure and later determination of the degree to which each variable is explained by each dimension or factor and is found to be a useful tool in decision-making process (Singh et al., 2009; Johnson $\&$ Wichern, 2015). FA was undertaken for 2009 and 2015 using the same set of variables but produced different outcomes depending on which subset of variables were more relevant in a given dimension for that period. Comparing these shifts through time, it is relevant to understand the dynamics of changes in the municipalities. Analyses were performed using SPSS version 22.

The Kaiser-Meyer-Olkin (KMO) test and Bartlett's Test of Sphericity (BTS) (Thompson, 2004) were used to determine whether the data were suitable for factorial analysis. The KMO test is an indicator that compares the observed correlation coefficient with the partial correlation coefficient on a scale ranging from 0 to 1 . In general, FA is not recommended for values below 0.5 (Hair et al., 2006). The BTS tests the null hypothesis that the correlation matrix is an identity matrix (correlations equal to zero). Rejection of the null hypothesis suggests that FA can be applied.

Next, the varimax rotation method with Kaiser normalization was used to improve the interpretation of the factorial solution. This method rearranges the variance observed in the original factors until a more understandable and theoretically more significant set of factors is achieved (Hair et al., 2006). Principal-component analysis (PCA) was used as the extraction method to identify how much each variable contributes to explaining the phenomenon and to organize the variables to interpret their dimensions (Johnson \& Wichern, 2015). Absent values were replaced by the mean in order to calculate the correlation matrices without changing the factor structure during normalization (Meijering, 2002).

FA has an interactive profile to search for the best model in terms of highest explanatory power (cumulative variance) with the highest dimension reduction power (least number of factors). Therefore, the statistical verification applied to the model considered that communality values had to be higher than 0.4 (Costello \& Osborne, 2005) for a variable to be considered pertinent for FA, which would imply a maximum uniqueness of 0.6 (Hair et al., 2006). The initial extraction criterion was the cumulative variance percentage, which indicates the specified cumulative percentage of the total variance extracted. The cut-off criterion considered for choosing the model and its dimensions were factors with eigenvalues above 1 (Kaiser criterion). Although using the same set of initial variables, models for each year may differ, reflecting the different key influence factors of the environmental management between years or random processes.

Once the key influence factors of each year were determined, iMEM could be calculated as follows. After estimating the factorial scores obtained from the factorial model, standardized factorial scores were obtained to calculate the iMEM and, therefore, to order the municipalities by performance. Standardization is necessary to prevent the result from being affected by data magnitude and/or data measurement unit (Hair et al., 2006). The iMEM was calculated based on the weighted means of the standardized factors $(\mathrm{Z})$ using the variance explained by each factor as a weight (Hair et al., 2006).

First, factor standardization was performed as follows: 


$$
Z_{i, j}=\frac{F_{i, j}-\min \left(F_{i, j}\right)}{\max \left(F_{i, j}\right)-\min \left(F_{i, j}\right)}
$$

where:

$F_{i j} F_{i j}=$ the (gross) factorial score of the $\mathrm{j}^{\text {th }}$ observation of the $\mathrm{i}^{\text {th }}$ factor;

$Z_{i j} Z_{i j}=$ the standardized factorial score of the $\mathrm{j}^{\text {th }}$ observation of the $\mathrm{i}^{\text {th }}$ factor;

"i" = the index used to represent factors;

and " $\mathrm{j}$ " = the index used to represent observations.

Then, the iMEM was calculated as:

$$
i M E M=\sum_{i=1}^{n} \lambda_{i} Z_{i, j}
$$

where:

$i M E M_{j} i M E M_{j}=$ municipal environmental management index of observation $\mathrm{j}$;

$\lambda_{i} \lambda_{i}=$ variance or eigenvalue of the $\mathrm{i}^{\text {th }}$ factor;

$Z_{i, j} Z_{i, j}=$ standardized factorial score of the $\mathrm{j}^{\text {th }}$ observation of the $\mathrm{i}^{\text {th }}$ factor;

$\mathrm{n}=$ number of factors.

A weighted representation of the iMEM is calculated as:

$$
i M E M_{j}^{*}=\frac{i M E M_{j}-\min (i M E M)}{\max (i M E M)-\min (i M E M)}
$$

The purpose of the use of (3) is ordering the iMEM on a scale from 0 to 1 , supporting the classification process described below. An inversion of some $F$ values was required to ensure that the iMEM would maintain a direct relationship with municipal environmental management quality; that is, municipalities with a higher index value would be those with better environmental management performance. Therefore, factors with a negative impact on environmental management had their ordination inverted prior to inclusion in the calculation of the iMEM.

Based on the iMEM, a ranking of the 143 municipalities was constructed for the two analyzed periods (2009 \& 2015) to classify each municipality according to environmental management performance. Four different categories were used (good, satisfactory, bad and very bad), and the final result was represented by maps. Classes were determined considering the similarity among different municipalities using k-means cluster analysis (Forgy, 1965; Lloyd, 1982), with the aim of reducing the sum of squares among management categories in order to obtain the smallest deviation from one category to another and thus the smallest cumulative deviation when summing the deviations from each class. Class separation used an algorithm from SPSS (as proposed by Hartigan, 1975) to calculate the k-means used to group municipalities based on the relative homogeneity of their calculated iMEM value. This analysis is useful because it aggregates municipalities with similar characteristics, thus facilitating the identification of groups with similar performance. Because this analysis is a relative comparison, municipalities classified as having good management, for example, represent the best scores among the municipalities of that group.

\subsection{Relationship between the iMEM and the explanatory variables}

Multiple regression analysis was used to describe the relationship between the iMEM values cal- 
culated for 2009 and 2015 and potential explanatory variables (Table 2). Considering the input variables as a matrix of explanatory variables in the regression for year $\boldsymbol{t}^{- \text {note that } t \text { does not refer to a time series }}$ but to the distinction between the cross-sectional multiple regression model constructed for 2009 and the model constructed for 2015 - to which a constant (unit vector) is added, forming matrix $\boldsymbol{X}_{\boldsymbol{t}}$, the set of multiple regressions to be calculated are as follows:

$$
\imath M E M_{i, t}=\overrightarrow{\beta_{t}} X_{t}+u_{t}
$$

where $\boldsymbol{I} \boldsymbol{M} \boldsymbol{E} \boldsymbol{M}_{\boldsymbol{i}, \boldsymbol{t}}$ represents the regression model that considers the calculated index as regressand and the input variables as regressors, with the aim of seeking new insights with regard to the iMEM based on variables that are not necessarily related to environmental quality. The regression model was estimated using generalized least squares (GLS)

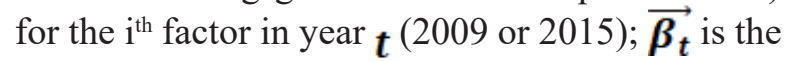
coefficient vector of the regression, and $\boldsymbol{u}_{\boldsymbol{t}}$ is an error term considered random and parameterized by a normal distribution with a mean of zero and a constant variance.

\section{Results}

At the beginning of the decentralization process of environmental management in 2009, three factors explained $73.3 \%$ of the total variance of the data via seven variables (Table 3). Factor 1 explained most of the total variance (29.8\%), showed the highest factor loadings with the variables pasture area (pasture) and number of cattle/hectare (cattle) and thus was named "livestock." Factor 2 (24.8\% of the variance) consisted of the variables heat sources, secondary vegetation and deforestation increase. Forest flammability and the increase of secondary vegetation and deforestation are all associated with forest impoverishment and, thus, closely related to aspects of "forest degradation". Finally, factor 3 (18.6\% of the variance) consisted of the variables pasture regeneration and crops, which is associated with the increase of permanent and temporary crops area and potential successive stages of land occupation in the Amazon, being interpreted as related to "agricultural production".

The iMEM calculated for each municipality based on the FA results enabled the ranking of the 143 Pará municipalities in decreasing order, with classes representing the performance of the municipalities in terms of environmental management in 2009 (Figure 1, Table 4). At the beginning of the decentralization process, approximately $25.5 \%$ (37) of municipalities were categorized as having good management, $21.7 \%$ (31) of municipalities had satisfactory management, $32.2 \%$ (46) of municipalities had bad management, and finally, 20.3\% (29) of municipalities had very bad management.

In 2015, six years after the decentralization of municipal environmental management, four factors explained $76.4 \%$ of the total variance of the data via nine variables (Table 5). Although the set of key influence factors had some resemblance to the 2009 model, other new factors composed by additional variables were also added to explain the 2015 model. Factor 1 explained most of the total variance $(33.8 \%)$ and was represented by the variables cattle, pasture and accumulated deforestation, thus, related to livestock and its effects and named "livestock" accordingly. Factor 2 explained $17.7 \%$ of the variance and consisted of the variables secondary vegetation, heat sources and pasture regeneration. 
As in 2009 , the three variables are also associated to cycles of forest impoverishment. However, in 2015 , pasture regeneration replaced deforestation increase, which although still relevant, appeared only in the 4th factor. Therefore, Factor 2 could also be interpreted as being related to "forest degradation". Factor 3 explained $12.9 \%$ of the variance and consisted of the variables quality of life index and infant mortality rate (the last one with a negative sign, indicating that it is inversely correlated with the former). Because this dimension is related to job, health and education, it was considered as being associated with "social impact". Lastly, factor 4 explained $11.9 \%$ of the variance with greater weight associated with the variable deforestation increase and was therefore named "deforestation".

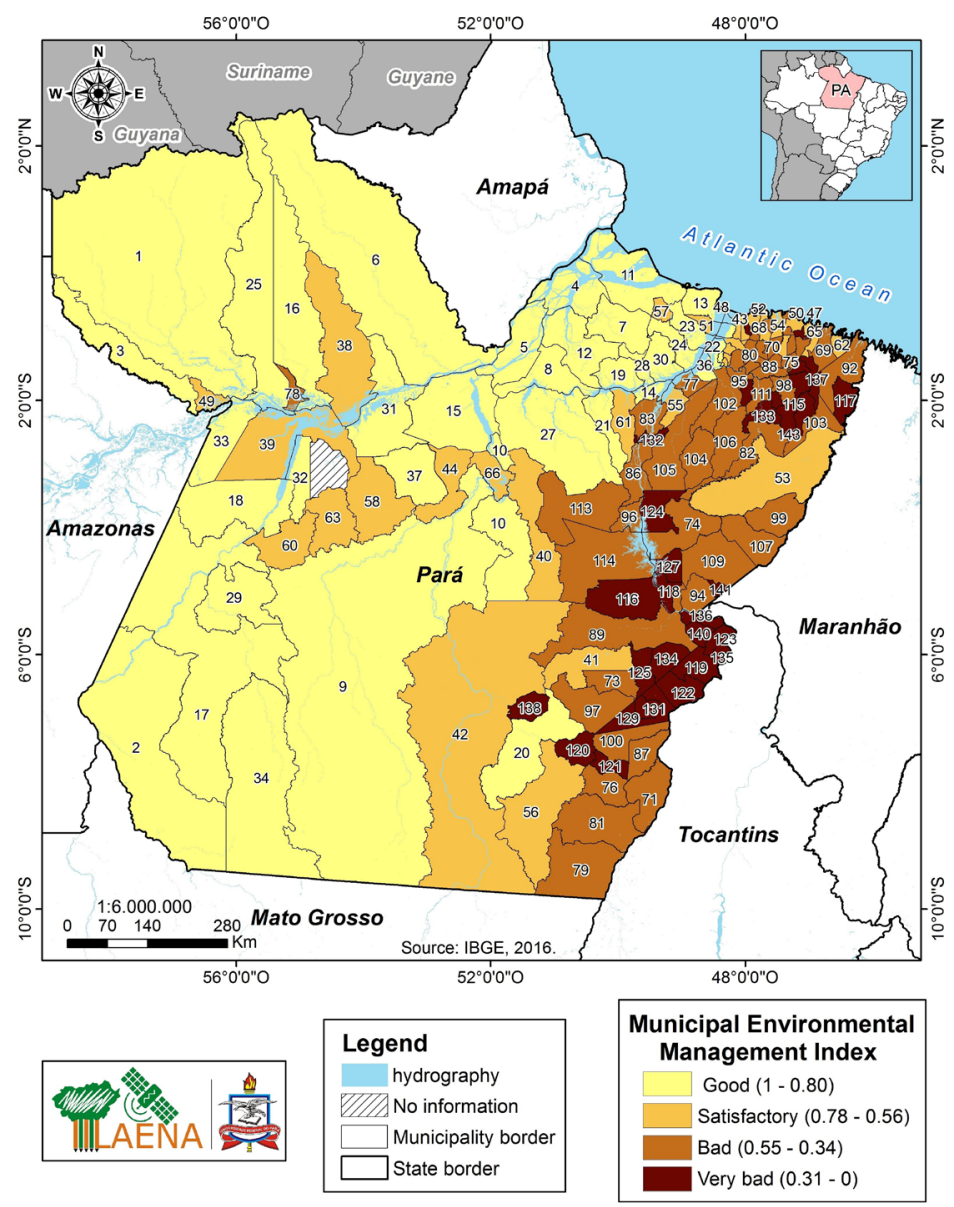

NAEA's Laboratory of Spatial Analysis Prof. Dr. Thomas Peter Hurtienne (LAENA), 2018.

FIGURE 1 - Municipal environmental-management performance in Pará, Brazil, at the beginning of administrative decentralization in 2009. The municipalities were ranked based on municipal environmental management index - iMEM (from good to very bad management). See Table 4 . 
TABLE 3 - Rotated component matrix* for 2009 with the factor loading and communality values for each variable, as well as the factor loadings and variances explained by the factors $(\mathrm{F})$.

\begin{tabular}{lcccc}
\hline \multicolumn{1}{c}{ Variables } & F1 & F2 & F3 & Communality \\
\hline Pasture & $\mathbf{0 . 9 6 1}$ & 0.104 & 0.001 & 0.935 \\
Cattle & $\mathbf{0 . 9 5 4}$ & -0.029 & -0.058 & 0.915 \\
Heat sources & -0.131 & $\mathbf{0 . 8 3 2}$ & 0.158 & 0.734 \\
Secondary vegetation & 0.342 & $\mathbf{0 . 6 9 9}$ & 0.194 & 0.643 \\
Deforestation increase & 0.014 & $\mathbf{0 . 6 8 7}$ & -0.163 & 0.499 \\
Pasture regeneration & -0.047 & 0.014 & $\mathbf{0 . 8 4 7}$ & 0.721 \\
Crops & 0.009 & 0.063 & $\mathbf{0 . 8 2 6}$ & 0.686 \\
\hline Sum of squared loadings & 2.087 & 1.74 & 1.305 & 5.132 \\
Trait percentage (\%) & 29.819 & 24.861 & 18.644 & 73.324 \\
\hline
\end{tabular}

* Sample suitability: KMO test $=0.53$; BST $(298.3)=21 ; \mathrm{P}<0.0001$.

TABLE 4 - Performance Ranking of Municipal Environmental Management - Year of 2009.

\begin{tabular}{|c|c|c|c|c|}
\hline \multicolumn{5}{|c|}{ Municipalities } \\
\hline 2 - Jacareacanga & 31 - Oeiras do Pará & 60 - São João de Pirabas & 89 - Castanhal & 118 - Irituia \\
\hline 3 - Muaná & 32 - Salvaterra & 61 - Bujaru & 90 - Rondon do Pará & $\begin{array}{l}119 \text { - Água Azul do } \\
\text { Norte }\end{array}$ \\
\hline 4 - Gurupá & 33 - Belterra & 62 - Tomé-Açu & 91 - São Domingos do C. & 120 - Bom Jesus do T. \\
\hline 6 - Melgaço & $\begin{array}{l}35 \text { - Santa Bárbara } \\
\text { do P. }\end{array}$ & 64 - Acará & 93 - Viseu & 122 - São João do A. \\
\hline 7 - Almeirim & 36 - Barcarena & 65 - Inhangapi & 94 - São Miguel do G. & 123 - Floresta do A. \\
\hline 8 - Oriximiná & 37 - Maracanã & 66 - Moju & 95 - Santa Maria das B. & 124 - Nova Ipixuna \\
\hline 12 - Chaves & 41 - Parauapebas & 70 - Santo Antônio do T. & 99 - Santa Maria do Pará & 128 - Redenção \\
\hline $\begin{array}{l}13 \text { - São S. da Boa } \\
\text { Vista }\end{array}$ & 42 - Monte Alegre & 71 - Ipixuna do Pará & 100 - Ourém & 129 - Itupiranga \\
\hline 14 - Alenquer & 43 - Santarém & 72 - São João da Ponta & 101 - Ulianópolis & 130 - Pacajá \\
\hline 15 - Óbidos & 44 - Marapanim & 73 - Tracuateua & 102 - Igarapé-Açu & 131 - Abel Figueiredo \\
\hline 16 - Bagre & 45 - Colares & 74 - Rurópolis & 103 - Placas & 132 - Vitória do Xingu \\
\hline 17 - Aveiro & $\begin{array}{l}46 \text { - Santa Cruz do } \\
\text { Arari }\end{array}$ & 75 - Santarém Novo & 104 - Nova Timboteua & 133 - Mãe do Rio \\
\hline 18 - Senador J. P. & $\begin{array}{l}47 \text { - São Félix do } \\
\text { Xingu }\end{array}$ & 76 - Bonito & 105 - São Francisco do P. & 134 - Curionópolis \\
\hline
\end{tabular}




\begin{tabular}{|c|c|c|c|c|}
\hline 19 - Curralinho & 48 - Cumaru do Norte & 77 - Primavera & 106 - Canaã dos Carajás & 135 - Bannach \\
\hline 20 - Afuá & 49 - Belém & 78 - Tailândia & 107 - Capitão Poço & 136 - Rio Maria \\
\hline 21 - Ponta de Pedras & 50 - Cametá & 79 - Vigia & 108 - Pau D'arco & 137 - São Geraldo do A. \\
\hline 22 - Porto de Moz & 51 - Marituba & 80 - Medicilândia & 109 - Aurora do Pará & $\begin{array}{l}138 \text { - Eldorado dos } \\
\text { Carajás }\end{array}$ \\
\hline 23 - Altamira & $\begin{array}{l}52 \text { - São Caetano } \\
\text { de O. }\end{array}$ & 81 - Augusto Corrêa & 110 - Capanema & 139 - Tucumã \\
\hline 24 - Itaituba & 53 - Ananindeua & 82 - Nova Esperança do P. & 111 - Peixe-Boi & 140 - Sapucaia \\
\hline 25 - Juruti & 54 - Quatipuru & 83 - Curuá & 112 - Conceição do Araguaia & $\begin{array}{l}141 \text { - São Domingos } \\
\text { do A. }\end{array}$ \\
\hline 26 - Igarapé-Miri & 55 - Novo Progresso & 84 - Bragança & 113 - Novo Repartimento & 142 - Piçarra \\
\hline $\begin{array}{l}27 \text { - Cachoeira do } \\
\text { Arari }\end{array}$ & $\begin{array}{l}56 \text { - Santa Isabel do } \\
\text { Pará }\end{array}$ & 85 - Uruará & 114 - Santa Luzia do Pará & 143 - Xinguara \\
\hline 28 - Portel & 57 - Salinópolis & 86 - Cachoeira do Piriá & 115 - Marabá & \\
\hline $\begin{array}{l}29 \text { - Ourilândia do } \\
\text { Norte }\end{array}$ & 58 - Abaetetuba & 87 - Dom Eliseu & 116 - Breu Branco & \\
\hline
\end{tabular}

TABLE 5 - Rotated component matrix* for 2015 with the factor loading and communality values for each variable, as well as the factor loadings and variances explained by the factors $(\mathrm{F})$ of the 2015 model.

\begin{tabular}{|c|c|c|c|c|c|}
\hline Cattle & 0.956 & 0.007 & 0.062 & 0.054 & 0.922 \\
\hline Accumulated deforestation & 0.711 & 0.341 & 0.208 & -0.076 & 0.671 \\
\hline Secondary vegetation & 0.153 & 0.884 & 0.118 & -0.239 & 0.876 \\
\hline Pasture regeneration & 0.241 & 0.646 & 0.163 & 0.098 & 0.512 \\
\hline Quality of life index & 0.018 & -0.027 & 0.814 & -0.03 & 0.665 \\
\hline Infant mortality rate & -0.179 & -0.087 & -0.737 & -0.064 & 0.588 \\
\hline Deforestation increase & -0.01 & 0.044 & 0.036 & 0.983 & 0.970 \\
\hline
\end{tabular}

* Sample suitability: KMO test $=0.62 ;$ BST $(497.269)=36 ; \mathrm{P}<0.0001$.

As for 2009, the iMEM calculated for each municipality based on the FA results enabled the ranking of the 143 municipalities of Pará representing the environmental management performance of the municipalities in 2015 (Figure 2, Table 6).
Six years after the beginning of the municipal environmental management decentralization process in Pará, approximately $21.7 \%$ (31) of the municipalities were categorized as having good management, $37.8 \%$ (54) had satisfactory management, $26.6 \%$ 
(38) had bad management, and $14.0 \%$ (20) of the municipalities had very bad management.

Considering both study periods and the 143 municipalities in Pará, those classified as having good management $(25.9 \%$ in 2009 and $21.7 \%$ in 2015) are mostly concentrated in the western and northern regions of the state. The poorer-performing municipalities in both periods $(20.3 \%$ in 2009 and $14.0 \%$ in 2015 ) are mostly concentrated in the eastern region of the state.

The relationship between the iMEM (2009 and 2015) and the input (independent) variables are shown in Table 7. The iMEM-2009 had a positive relationship with the variables number of internet
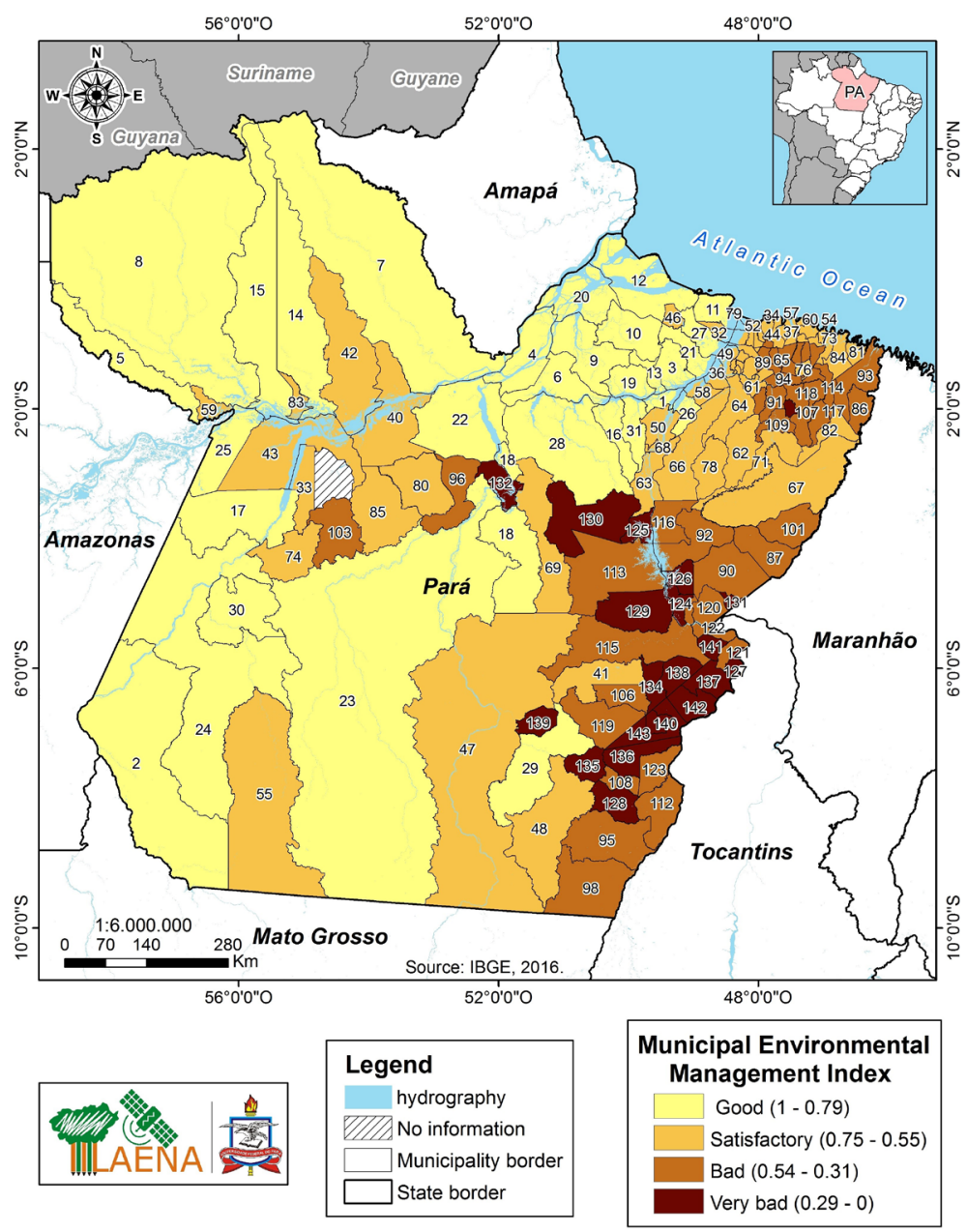

NAEA's Laboratory of Spatial Analysis Prof. Dr. Thomas Peter Hurtienne (LAENA), 2018.

FIGURE 2 - Municipal environmental-management performance in Pará, Brazil, in 2015. The municipalities were ranked based on municipal environmental management index - iMEM (from good to very bad management). See Table 6. 
users (internet), annual population growth rate and population density and a negative relationship with the number of phone lines per inhabitant (phone) and the value of rural credit financed per municipality. The iMEM-2015 had a positive relationship with the variables phone, population density and number of protected areas and a negative rela- tionship with the variables rural credit, rural environmental cadaster of properties and municipal gross domestic product (GDP). The models showed adjusted $\mathrm{R}^{2}$ values equal to 0.80 for 2009 and 0.70 for 2015, confirming the strong relationship between the explanatory variables and the iMEM.

TABLE 6 - Performance Ranking of Municipal Environmental Management - Year 2015.

\begin{tabular}{|c|c|c|c|c|}
\hline \multicolumn{5}{|c|}{ Municipalities } \\
\hline 1 - Limoeiro do Ajuru & 30 - Trairão & 59 - Terra Santa & 88 - Concórdia do Pará & 117 - Garrafão do Norte \\
\hline 2 - Jacareacanga & 31 - Oeiras do Pará & 60 - São João de Pirabas & 89 - Castanhal & 118 - Irituia \\
\hline 4 - Gurupá & 33 - Belterra & 62 - Tomé-Açu & 91 - São Domingos do C. & 120 - Bom Jesus do T. \\
\hline 5 - Faro & 34 - Curuçá & 63 - Baião & 92 - Goianésia do Pará & 121 - Brejo Grande do A. \\
\hline 7 - Almeirim & 36 - Barcarena & 65 - Inhangapi & 94 - São Miguel do G. & 123 - Floresta do A. \\
\hline 8 - Oriximiná & 37 - Maracanã & $66-$ Moju & 95 - Santa Maria das B. & 124 - Nova Ipixuna \\
\hline 9 - Breves & 38 - Benevides & 67 - Paragominas & 96 - Brasil Novo & 125 - Tucuruí \\
\hline $\begin{array}{l}13 \text { - São S. da Boa } \\
\text { Vista }\end{array}$ & 42 - Monte Alegre & 71 - Ipixuna do Pará & 100 - Ourém & 129 - Itupiranga \\
\hline 14 - Alenquer & 43 - Santarém & 72 - São João da Ponta & 101 - Ulianópolis & 130 - Pacajá \\
\hline 15 - Óbidos & 44 - Marapanim & 73 - Tracuateua & 102 - Igarapé-Açu & 131 - Abel Figueiredo \\
\hline 16 - Bagre & 45 - Colares & 74 - Rurópolis & 103 - Placas & 132 - Vitória do Xingu \\
\hline 17 - Aveiro & $\begin{array}{l}46 \text { - Santa Cruz do } \\
\text { Arari }\end{array}$ & 75 - Santarém Novo & 104 - Nova Timboteua & 133 - Mãe do Rio \\
\hline 18 - Senador J. P. & $\begin{array}{l}47 \text { - São Félix do } \\
\text { Xingu }\end{array}$ & 76 - Bonito & 105 - São Francisco do P. & 134 - Curionópolis \\
\hline 24 - Itaituba & 53 - Ananindeua & 82 - Nova Esperança do P. & 111 - Peixe-Boi & 140 - Sapucaia \\
\hline
\end{tabular}




\begin{tabular}{lllll}
25 - Juruti & 54 - Quatipuru & 83 - Curuá & 112 - Conceição do Araguaia & 141 - São Domingos do A. \\
26 - Igarapé-Miri & 55 - Novo Progresso & 84 - Bragança & 113 - Novo Repartimento & 142 - Piçarra \\
& 56 - Santa Isabel do & & 114 - Santa Luzia do Pará & 143 - Xinguara \\
$\begin{array}{l}27 \text { - Cachoeira do Arari } \\
\text { Pará }\end{array}$ & 57 - Salinópolis & 86 - Uruará & 115 - Marabá & \\
$\begin{array}{l}29 \text { - Ourilândia do } \\
\text { Norte }\end{array}$ & 58 - Abaetetuba & 87 - Dom Eliseu & 116 - Breu Branco & \\
\hline
\end{tabular}

TABLE 7 - Results of the multiple regressions for the iMEM-2009 and iMEM-2015 in relation to significant input variables.

\begin{tabular}{|c|c|c|c|c|c|}
\hline Variable Y & & iMEM-2009 & t value & iMEM-2015 & t value \\
\hline INTERCEPT & & $0.81354 *$ & 2.3539 & $1.01457 * *$ & 6,7910 \\
\hline Rural environmental cadaster & & & & $-0.18579 * *$ & -3.3568 \\
\hline Rural credit & & $-0.000167 *$ & -2.5849 & $-9.74364 \mathrm{e}-05^{* *}$ & -3.2010 \\
\hline \multicolumn{6}{|l|}{ State tax } \\
\hline Internet & & $0.28197 * *$ & 2.9103 & & \\
\hline GDPm & & & & $-0.03855^{* *}$ & $-2,1405$ \\
\hline Pop. growth rate & & $0.68521 * *$ & 3.5502 & & \\
\hline F Test & P-VALUE(F) & $<0.001$ & & $<0.01$ & \\
\hline
\end{tabular}

$* \mathrm{p} \leq 0.05 ; * * \mathrm{p} \leq 0.01$

\section{Discussion}

\subsection{Determinant factors of municipal environmental management in Pará}

Overall, the key influence factors on MEM are consistent with the drivers of forest conversion in the Amazon (Hecht, 1993; Kaimowitz et al., 2004; Nepstad et al., 2014). In general, deforestation, livestock, agricultural production and the consequent forest degradation and impact on life quality were relevant for local environmental management, even with some variation between periods.

The factor "livestock" had the highest explained variance in FA in both years, which is consistent with a dominant (large areas of pasture) and extensive activity (few heads of cattle per hectare) in Pará, often used simply as a form of illegal land appropriation, resulting in large areas of abandoned pastures after few years. Livestock is one of the most important economic activities in Pará (6.2 
$\%$ of state GDP; FAPESPA, 2014), increasing its production from nearly 17 million heads of cattle in 2009 to 20 million heads in 2015, assuming the 5th position of largest cattle producers in Brazil (IBGE, 2017b). The strong correlation between livestock activity and deforestation in the Amazon has been emphasized in several studies (Hecht, 1993; Barona et al., 2010; Nepstad et al., 2014) and it is also captured in the models in this study. As the municipalities are judged and penalized or rewarded according to their deforestation rates, monitoring the growth of livestock activity is an important task for MEM. In the 2009 model, the deforestation increase was an important variable, but cumulative deforestation appeared stronger in 2015. This possibly reflected on the effectiveness of several policies for deforestation reduction in the Amazon in the last decade (Moutinho et al., 2016).

The second most important factor for municipal environmental management in both analyzed periods was forest degradation, with a higher explained variance (24.8\%) in 2009 than in 2015 (17.7\%). Forest degradation is highly impactful and follows livestock and deforestation (Hecht, 1993; Nepstad et al., 2014). The conversion of forest to other land uses, as well as the high incidence of abandoned pastures, increases the occurrence of fires and secondary vegetation succession in a positive feedback effect on the gradual impoverishment of forest areas in the Amazon (Nepstad et al., 1999).

Another important factor was agricultural production, which explains $18.6 \%$ of the total variance in the 2009 model but excluded from the 2015 model due to a low communality level. Usually associated with forest conversion, agricultural production is an economic activity of great importance in the municipalities of Pará ( $4.5 \%$ of state GDP), favored by climate conditions and large extensions of degraded areas with economic potential to be used mainly for grain production (e.g., soybean). The larger the agricultural production becomes, the greater the pressure will be on environmental management, requiring better control from municipalities in Pará.

The factor social impact, present only in the 2015 model, had a positive relationship with the quality of life index and a negative relationship with infant mortality rate. The increase in the relative importance of variables related to social impact six years after the beginning of the decentralization policies can be understood as a possible positive change. Given the clear urbanization of the Amazon population (Guedes et al., 2009), city conditions become relevant for environmental management actions. Infant mortality in Brazil is still primarily associated with basic sanitation, water quality, pollution and associated diseases (MS, 2015). The worse these conditions are, the higher the rate of infant mortality and the less efficient environmental management is in minimizing these impacts. Conversely, the quality of life of the population reflects that broader elements of socioenvironmental progress, such as employment, income, education and health, are being achieved. The inclusion of social impact indicators in the 2015 model reflects the growth of medium-sized Brazilian cities in recent years (IBGE, 2017d), pressuring municipalities to meet the environmental demands of rural and urban areas within their limits.

\subsection{Municipal environmental management}

The iMEM classified 68 (47.2\%) municipalities in 2009 and 85 (59.5\%) municipalities in 2015 as having good/satisfactory management. Overall, there was an improvement, although the causes 
are not clear. Previous studies undertaken in Latin American countries showed that local engagement in environmental governance may be associated with institutional support, public policies incentives or even the local distribution of benefits (Andersson et al., 2006; Larsen, 2011). In this study, institutional support seemed not to be responsible for the changes. Considering only those municipalities formally empowered by the state to undertake decentralized management (e.g. with capacity building and additional resources), 7 of 10 had good management in 2009 according to iMEM, in contrast to only $16 \%$ (11 of 69) of the municipalities in 2015. Therefore, it seems that the administrative adherence to decentralization in Pará until 2015 was higher than its effectiveness ("paper decentralization"). In other words, state government interests in rapidly increasing the number of municipalities that adhere to decentralization may be taking precedence over the effectiveness of the process.

Present and past public policies, however, seem to influence and drive the local economic culture, which ultimately may affect environmental management. During Brazil's military regime (1964-1985), there was a boom in development projects (via migrations, infrastructure projects, industrialization, natural resources exploration, corporate farming and ranching) to populate and integrate the Amazon with the rest of the country and those were responsible for large areas of forest conversion (Wood \& Perz, 1996; De Lima \& Buszynski, 2011). The impact of this policy was uneven across the Amazon and within Amazon states. That may explain or at least influence the geography of better- and poorer-performing municipalities in Pará shown in this study. Better-performing municipalities located in western and northern regions were less influenced by the
Amazon integration and colonization policies of the military regime and many municipalities associated with forest-extractive economies showed higher percentages of forest cover in 2015. In some cases, however, passive conservation may not be ruled out and environmental management may have benefited from this. On the other hand, poorer-performing municipalities in both periods are mostly concentrated in the eastern region of the state, on the old frontiers of integration policies. This region is characterized by high deforestation rates, extensive livestock farming and forest degradation. Some examples are the municipalities of São Félix do Xingu, Cumaru do Norte and Marabá, the largest cattle producers in Pará (IBGE 2017a). However, in the same region, municipalities characterized by economies other than livestock farming (e.g., palm plantations in the microregion of Tomé-Açú and agroforestry in the microregion of Cametá) stand out as having satisfactory environmental management in 2015. That might mean that the emergence of alternative and diverse economies is likely to occur in the wake of changes in environmental policy and new market demands. Brazil's environmental policy in the twenty-first century has evolved and increasingly supports sustainable economies. Studies have shown that the sustainable livestock intensification associated with the adoption of good practices in agriculture, pasture maintenance, and restoration of environmental liabilities is feasible and has the potential to prevent further deforestation in the Amazon (Garcia et al., 2017). Local environmental management may be key to supporting sustainable economic alternatives. Firstly, as the cost may exceed benefits from the local perspective, the local government must be interested in carrying out this mandate. 
Local politicians play a critical role in environmental governance because they may adhere to, filter or completely ignore their new decentralized mandate (Andersson et al., 2006). It was shown that local politicians in Guatemala and Bolivia may increase their will for engagement in environmental management if they perceive benefits associated with a given policy (Andersson et al., 2006). The findings of this study suggested the same since the state government attracts local governments to the decentralized regime by offering resources and training. However, the results regarding municipality performance were unsatisfactory. Another example in Pará also revealed the same pattern. Since a state policy designed to curb deforestation (the Green Municipalities Program) was implemented in Pará in 2011 which promises benefits for those who follow its conditions (PMV, 2016), 106 of the 144 municipalities adhered to it until 2015. However, according to the iMEM-2015, only 54 of those municipalities were classified as having good/satisfactory management. On the other hand, it is noteworthy that the withdrawal of previous benefits works the same way for engagement of politicians. For instance, until 2015, all 19 municipalities of Pará on the federal government red list of deforesters and under financial restrictions (MMA, 2013) adhered to decentralized environmental management as a condition to minimize environmental issues and escape from penalizations. Of the total, 10.5\% (2) were characterized as having good management in 2015 .

The foregoing examples illustrate the impact of environmental policies on local government and also confirm the potential of a monitoring tool to reveal that the policy is still far from effective with much room for improvement.

\subsection{Elements that affect MEM}

Municipal environmental management was affected by a set of factors, which changed over time according to the evolution of the municipality and to the implementation of public policies. At the beginning of decentralization in 2009, the population (growth and density) and the internet had a positive influence on environmental management, whereas telephony (mobile and fixed phones) and rural credit had a negative impact. Six years later (2015), the population density, phone and protected areas were relevant for better management, while rural credit, the rural environmental cadaster and municipal GDP had a negative impact.

Communication access may be considered a facilitator of environmental management and increase information access. In Pará's municipalities, access to mobile phones increased by $141 \%$ between 2009 and 2015 whereas access to internet increased only by $34 \%$. That may explain the increasing importance of phones (instead of the internet) for MEM between the two years. Furthermore, between the two periods, the population tended to concentrate $(5.8 \%)$ rather than grow $(-33 \%)$, increasing the importance of population density in 2015. Rural credit had a negative impact on environmental management in both years. Usually, rural credit focuses on agriculture and livestock and stimulates them without environmental sustainability constraints, becoming a liability for MEM. The negative impact of the rural environmental cadaster in 2015 may seem surprising as its goal was to bring environmental regulation of properties where it was absent. However, its creation in 2012 caused negative externalities, such as new deforestation 
waves as a way to occupy public lands illegally and then try to "legalize" them via cadaster (Azevedo et al., 2017). Hence its initial negative effect on environmental management despite the expected tendency for it to promote better management. Likewise, the negative impact of a stronger municipal economy (GDP) may seem counterintuitive. The economic growth of municipalities in Pará, however, is strongly related to livestock and agriculture, as well as natural resource extraction (e.g., mining and logging). When the economy grows (GDP), deforestation increases (Andersen \& Reis, 2015), exerting more pressure on environmental management. The economy characterized by rapid growth based on the exploitation of natural resources without the counterpart of improvements in population life quality, following a boom-collapse pattern, is characteristic of Amazon municipalities (Celentano \& Veríssimo, 2007).

\section{Conclusion}

Overall, land-use changes determined municipal environmental management performance in the Amazon in both of the analyzed periods. This suggests that forest cover conversion in Pará is still predominant and challenging for municipal environmental management, requiring better control of its drivers and consequences. It is not by chance, then, that municipal performance between 2009 and 2015 showed some improvements but they were slower than necessary. Municipalities have been encouraged to adhere to the decentralization regime by the state government but the emphasis in recent years seems to have been restricted to formal adherence only. In a context where unsustainable economies prevail, the geography of poorly performing municipalities as well as the loose local adherence to decentralization point to the role of public policies in stimulating environmental management as well as how significant they are to local realities and how well they can engage local politicians.

It is important to emphasize, therefore, that the decentralization of environmental management depends on synergic policies in a broad context with the penalty of not achieving the desired effectiveness. Coordinated environmental policies may have larger chances of impact in local governments. However, many policies with a profound impact at the municipal level are elaborated in higher hierarchical levels. For instance, economies centered on forest conversion activities and their various associated incentives (e.g. rural credits) continue to present a challenge to effective environmental management in the Amazon. Environmental management would benefit from the use of sustainable and technological practices in addition to environmental planning, land tenure security and recovery of deforested areas. Additionally, decentralized regimes should be supported by appropriate institutional conditions, capacities and resources. It seems unfair to leave local government standing alone unequipped to face the consequences of the lack of incentives for sustainable economies in the Amazon, most often established out of their jurisdiction. As an ongoing process in Brazil, decentralized environmental management needs time to locally adjust, but the responsibility for its success or failure should be shared among the different hierarchical governmental levels.

Considering that municipal environment management after decentralization processes may work better in the context of mechanisms of accountabili- 
ty (Andersson et al, 2006; Coleman \& Fleischman, 2012), there is much to be done in the Amazon region. Without transparency, accountability and pressure from society, local politicians or institutions may feel comfortable with inactivity. Even the risk of elite capture of the local governance process was identified in other studies (Persha \& Andersson, 2014; Viana et al., 2016). This study emphasized the importance and need of monitoring the performance of the municipal environment management to bring visibility to the task, improve the decentralization process and successfully achieve its environmental goals. Making environmental management more transparent for public managers and civil society is the first step to better local governance.

\section{Acknowledgments}

We thank W. Magnusson, A. C. de Santana, E. Nakano, S. L. Bomfim, V. Ribeiro and P. Moutinho for their valuable comments on a previous version of the manuscript. This study was partly supported by a CAPES' (Coordenação de Aperfeiçoamento de Pessoal de Nível Superior) doctorate scholarship to B.E.B.S.

\section{References}

Andersen, L. E.; Reis, E. J. Deforestation, development, and government policy in the Brazilian Amazon: an econometric analysis. Discussion Paper 69. Institute for Applied Economic Research - IPEA, 2015. Available at: http://repositorio. ipea.gov.br/bitstream/11058/4832/1/DiscussionPaper_69. pdf. Accessed in: nov. 2017.

Andersson, K.; Gibson, C.; Lehoucq., F. Municipal politics and forest governance: comparative analysis of decentra- lization in Bolivia and Guatemala. World Development, 34(3), 576-95, 2006. doi: 10.1016/j.worlddev.2005.08.009

Andersson, K.; Laerhoven, F. V. From local strongman to facilitator: institutional incentives for participatory municipal governance in Latin America. Comparative Political Studies, 40(7), 1085-1111, 2007. doi: 10.1177/0010414006288977

Azevedo, A. A.; Rajão, R. L.; Costa, M.; Stabeli, M. C. C.; Macedo, M. N.; Dos Reis, T. N. P.; Alencar A.; Soares-Filho, B.; Pacheco, R. Limits of Brazil's Forest Code as a means to end illegal deforestation. PNAS, 114(29), 7653-7658. 2017. doi: 10.1073/pnas. 1604768114

BACEN - Banco Central do Brasil. Crédito Rural. Ano base 2009 e 2013. 2017. Available at: http://www.bcb.gov. br/pt-br/\#!/n/CREDRURAL. Accessed in: May. 2017.

Barona, E.; Ramankutty, N.; Hyman, G.; Coomes, O. T. The role of pasture and soybean in deforestation of the Brazilian Amazon. Environmental Research Letters, 5, 024002, 2010. doi: 10.1088/1748-9326/5/2/024002/meta

Bomfim, S. L. Índice de clima econômico para concessões florestais. PhD thesis. Universidade de Brasília (UNB), 2014. Available at: http://repositorio.unb.br/handle/10482/17230. Accessed in: Aug. 2017.

Celentano, D.; Veríssimo, A. O Avanço da Fronteira na Amazônia: do boom ao colapso. O Estado da Amazônia Indicadores, 48. Belém: Imazon, 2007.

Coleman, E. A.; Fleischman, F. D. Comparing Forest Decentralization and Local Institutional Change in Bolivia, Kenya, Mexico, and Uganda. World Development, 40(4), 836-849, 2012. doi: 10.1016/j.worlddev.2011.09.008

Costello, A. B.; Osborne J. W. Best practices in exploratory factor analysis: Four recommendations for getting the most from your analysis. Practical assessment, research \& evaluation. 2005. Available at: http://pareonline.net/getvn. asp? $\mathrm{v}=10 \& \mathrm{n}=7$

De Lima, I. B.; Buszynski, L. Local environmental governance, public policies and deforestation in Amazonia. Management of Environmental Quality: An International Journal, 22(3), 292-316, 2011. doi: 10.1108/14777831111122888

Falleti, T. Decentralization and subnational politics in Latin America. Cambridge University Press, Cambridge, 2010. 
Fapespa - Fundação Amazônia de Amparo a Estudos e Pesquisas. (2014) Estatística Municipal do Pará 2014. Available at: $<$ http://www.fapespa.pa.gov.br/produto $>$. Accessed in: May. 2017.

Fapespa - Fundação Amazônia de Amparo a Estudos e Pesquisas. Anuário Estatístico do Pará 2015, 2015. Available at: $<$ http://www.fapespa.pa.gov.br/anuario_estatistico $>$ Accessed in: May. 2017.

FIRJAN - Índice FIRJAN de Desenvolvimento Municipal. Federação das Indústrias do Estado do Rio de Janeiro. 2015. Available at: $<$ http://www.firjan.com.br/ifdm/downloads/>. Accessed in: Oct. 2017.

Forgy, E.W. Cluster analysis of multivariate data: efficiency versus interpretability of classifications. Biometrics, 21,768-769, 1965.

Galbadón, A. J. La descentralización de la gestón ambiental en América Latina. Reforma y Democracia, 45,1-77, 2009.

Garcia, E.; Ramos Filho.; F. S. V; Mallmann, G. M; Fonseca, F. Costs, benefits and challenges of sustainable livestock intensification in a major deforestation frontier in the Brazilian Amazon. Sustainability, 9(1), 158, 2017. doi: $10.3390 /$ su 9010158

Gibson, C.; Lehoucq, F. The local politics of decentralized environmental policy in Guatemala. Journal of Environment and Development, 12(1), 28-49, 2003. doi: 10.1177/1070496502250437

Guedes, G.; Costa, S.; Brondízio, E. Revisiting the hierarchy of urban areas in the Brazilian Amazon: a multilevel approach. Population and Environment, 30(4-5), 159-192, 2009.

Hair, J.; Black, W.; Babin, B.; Anderson, R.; Tatham, R. Multivariate data analysis (6th ed.). Pearson Prentice Hall. Uppersaddle River, N.J, 2006.

Hartigan, J. A. Clustering algorithms. John Willey and Sons. New York, NY, 1975.

Hecht, S. B. The Logic of Livestock and Deforestation in Amazonia. BioScience, 43(10), 687-695, 1993. doi: $10.2307 / 1312340$

IBGE - Instituto Brasileiro de Geografia e Estatística. Indicadores de desenvolvimento sustentável. 2015. Available at: $<$ https://ww2.ibge.gov.br/home/geociencias/recursosnaturais/ids/default_2015.shtm> Aaccessed in: Jan. 2017.

IBGE - Instituto Brasileiro de Geografia e Estatística. SIDRA. 2017a. Available at: <http://www.sidra.ibge.gov.br>. Accessed in: Sept. 2017.

IBGE - Instituto Brasileiro de Geografia e Estatística. Pesquisa de Informações Básicas Municipais. 2017b. Available at: <https://ww2.ibge.gov.br/home/estatistica/ economia/perfilmunic/defaulttab1_perfil.shtm> Accessed in: Feb. 2017.

IBGE - Instituto Brasileiro de Geografia e Estatística. Taxa de crescimento populacional. 2017c. Available at: $<\mathrm{ftp}: / / \mathrm{ftp}$. ibge.gov.br> Accessed in: Feb. 2017.

IBGE - Instituto Brasileiro de Geografia e Estatística. IBGE Cidades, 2017d. Available at: $<$ https://cidades.ibge.gov.br/> Accessed in: Dec. 2017.

INPE - Instituto Nacional de Pesquisas Espaciais. DEGRAD - Mapeamento da Degradação Florestal na Amazônia Brasileira. 2017b. Available at: $<$ http://www.obt.inpe. $\mathrm{br} /$ degrad//>. Accessed in: August 2017.

INPE - Instituto Nacional de Pesquisas Espaciais. PRODES - Sistema de Monitoramento do Desmatamento na Amazônia Legal. 2017a. Available at: <http://www.dpi. inpe.br/prodesdigital/prodes.php> Accessed in: Aug. 2017.

INPE - Instituto Nacional de Pesquisas Espaciais. Projeto Terraclass. 2017c. Available at: <http://www.inpe.br/cra/ projetos_pesquisas/dados_terraclass.php $>$. Accessed in: Aug. 2017.

IPS Amazônia - Índice de Progresso Social na Amazônia Brasileira. 2014. Belém: Imazon e Social Progress Imperative. Available at: <http://www.ipsamazonia.org. br/\#aspects $\% 5 \mathrm{~B} \% 5 \mathrm{D}=1 \&$ aspects $\% 5 \mathrm{~B} \% 5 \mathrm{D}=2$ \&aspect$\mathrm{s} \% 5 \mathrm{~B} \% 5 \mathrm{D}=7 \&$ aspects $\% 5 \mathrm{~B} \% 5 \mathrm{D}=12 \& \mathrm{ma}$ 
Corrigendum to: The impact of decentralization policies: the environmental performance applied to municipalities of the Amazon

Corrigendum para: $O$ impacto de políticas descentralizadas: 0 desempenho ambiental aplicado a municípios da Amazônia

Benedito Evandro Barros da SILVA ${ }^{1,2^{*}}$, Claudia AZEVEDO-RAMOS ${ }^{3}$, Hilder André Bezerra FARIAS ${ }^{4}$

${ }^{1}$ Programa de Pós-Graduação em Desenvolvimento Sustentável dos Trópicos Úmidos, Universidade Federal do Pará (UFPA), Belém, PA, Brasil.

${ }^{2}$ Secretaria de Estado de Meio Ambiente do Pará (SEMAS/PA), Belém, PA, Brasil.

${ }^{3}$ Núcleo de Altos Estudos da Amazônia (NAEA), Universidade Federal do Pará (UFPA), Belém, PA, Brasil.

${ }^{4}$ Departamento de Economia, Universidade Federal do Pará (UFPA), Belém, PA, Brasil.

*E-mail of contact: evandroourem@yahoo.com.br

Article received on September 22, 2018, final version accepted on May 23, 2019, published on August 2019. 
The original article can be found online at:

http://dx.doi.org/10.5380/dma.v51i0.61705

Table 4 has been corrected, as follows:

Table 4 - Performance Ranking of Municipal Environmental Management - Year 2009.

\begin{tabular}{|c|c|c|c|c|}
\hline \multicolumn{5}{|c|}{ Municipalities } \\
\hline \multirow{3}{*}{1 - Oriximiná } & \multirow{3}{*}{30 - Muaná } & 59 - Santo & 88 - São Miguel do & 117 - Cachoeira do \\
\hline & & Antônio do $\mathrm{T}$. & G. & Piriá \\
\hline & & & & 118 - Nova \\
\hline \multirow[t]{2}{*}{2 - Jacareacanga } & \multirow[t]{2}{*}{31 - Prainha } & 60 - Rurópolis & 89 - Marabá & Ipixuna \\
\hline & & $61-$ Oeiras do & & 119 - São Geraldo \\
\hline \multirow[t]{2}{*}{3 - Faro } & \multirow[t]{2}{*}{32 - Belterra } & Pará & 90 - Peixe-Boi & do A. \\
\hline & & 62 - Augusto & 91 - São Francisco & \\
\hline \multirow[t]{2}{*}{4 - Afuá } & \multirow{2}{*}{$\begin{array}{l}33 \text { - Juruti } \\
34 \text { - Novo }\end{array}$} & Corrêa & do $P$. & 120 - Bannach \\
\hline & & & & \\
\hline \multirow[t]{2}{*}{5 - Gurupá } & \multirow[t]{2}{*}{ Progresso } & 63 - Placas & 92 - Viseu & 121 - Pau D'arco \\
\hline & & 64 - Nova & 93 - Santa Maria & \\
\hline \multirow[t]{2}{*}{6 - Almeirim } & \multirow[t]{2}{*}{35 - Ananindeua } & Timboteua & do Pará & 122 - Piçarra \\
\hline & & & 94 - Bom Jesus do & 123 - Brejo \\
\hline \multirow[t]{2}{*}{7 - Anajás } & \multirow[t]{2}{*}{36 - Barcarena } & 65 - Tracuateua & $\mathrm{T}$. & Grande do A. \\
\hline & & 66 - Vitória do & & \\
\hline 8 - Melgaço & $\begin{array}{l}37 \text { - Medicilândia } \\
38 \text { - Monte }\end{array}$ & Xingu & 95 - Bujaru & 124 - Breu Branco \\
\hline 9 - Altamira & Alegre & 67 - Marituba & $\begin{array}{l}96 \text { - Tucuruí } \\
97 \text { - Água Azul do }\end{array}$ & 125 - Curionópolis \\
\hline 10 - Senador J. P. & 39 - Santarém & 68 - Marapanim & Norte & 126 - Ourém \\
\hline \multirow[t]{2}{*}{11 - Chaves } & \multirow[t]{2}{*}{40 - Anapu } & 69 - Bragança & 98 - Irituia & 127 - Jacundá \\
\hline & & & & 128 - São João da \\
\hline \multirow[t]{2}{*}{12 - Breves } & \multirow{2}{*}{$\begin{array}{l}41 \text { - Parauapebas } \\
42 \text { - São Félix do }\end{array}$} & 70 - Igarapé-Açu & 99 - Ulianópolis & Ponta \\
\hline & & 71 - Conceição do & & \\
\hline 13 - Soure & Xingu & A. & 100 - Rio Maria & 129 - Xinguara \\
\hline 14 - Limoeiro do & 43 - São Caetano & 72 - Santa Isabel & & \\
\hline Ajuru & de $O$. & $\begin{array}{l}\text { do P. } \\
73 \text { - Canaã dos }\end{array}$ & 101 - Salinópolis & 130 - Primavera \\
\hline 15 - Porto de $\mathrm{Moz}$ & 44 - Brasil Novo & Carajás & 102 - Acará & 131 - Sapucaia \\
\hline
\end{tabular}




\begin{tabular}{|c|c|c|c|c|}
\hline 16 - Alenquer & $\begin{array}{l}45 \text { - Santa } \\
\text { Bárbara do P. }\end{array}$ & $\begin{array}{l}74 \text { - Goianésia do } \\
\text { Pará }\end{array}$ & $\begin{array}{l}103 \text { - Nova E. do } \\
\text { P. }\end{array}$ & $\begin{array}{l}132 \text { - Mocajuba } \\
133 \text { - Aurora do }\end{array}$ \\
\hline 17 - Itaituba & 46 - Benevides & 75 - Bonito & 104 - Tailândia & $\begin{array}{l}\text { Pará } \\
134 \text { - Eldorado dos }\end{array}$ \\
\hline 18 - Aveiro & 47 - Quatipuru & 76 - Redenção & 105 - Moju & $\begin{array}{l}\text { C. } \\
135 \text { - Palestina do }\end{array}$ \\
\hline $\begin{array}{l}19 \text { - Curralinho } \\
20 \text { - Ourilândia do }\end{array}$ & 48 - Vigia & 77 - Abaetetuba & 106 - Tomé-Açu & $\begin{array}{l}\text { Pará } \\
136 \text { - São João do }\end{array}$ \\
\hline Norte & $\begin{array}{l}49 \text { - Terra Santa } \\
50 \text { - São João de }\end{array}$ & $\begin{array}{l}78 \text { - Curuá } \\
79 \text { - Santana do }\end{array}$ & 107 - Dom Eliseu & $\begin{array}{l}\text { A. } \\
137 \text { - Santa Luzia }\end{array}$ \\
\hline 21 - Bagre & P. & A. & $\begin{array}{l}108 \text { - Terra Alta } \\
109 \text { - Rondon do }\end{array}$ & do Pará \\
\hline $\begin{array}{l}22 \text { - Belém } \\
23 \text { - Cachoeira do }\end{array}$ & 51 - Salvaterra & $\begin{array}{l}80 \text { - Castanhal } \\
81 \text { - Santa M. das }\end{array}$ & $\begin{array}{l}\text { Pará } \\
110 \text { - Santarém }\end{array}$ & $\begin{array}{l}138 \text { - Tucumã } \\
139 \text { - Concórdia }\end{array}$ \\
\hline Arari & 52 - Curuçá & $\begin{array}{l}\text { B. } \\
82 \text { - Ipixuna do }\end{array}$ & $\begin{array}{l}\text { Novo } \\
111 \text { - São }\end{array}$ & $\begin{array}{l}\text { do Pará } \\
140 \text { - São }\end{array}$ \\
\hline 24 - Ponta de Pedras & 53 - Paragominas & Pará & Domingos do $\mathrm{C}$. & $\begin{array}{l}\text { Domingos do A. } \\
141 \text { - Abel }\end{array}$ \\
\hline 25 - Óbidos & 54 - Maracanã & $\begin{array}{l}83 \text { - Cametá } \\
84 \text { - Magalhães }\end{array}$ & 112 - Capanema & Figueiredo \\
\hline 26 - Colares & $\begin{array}{l}55 \text { - Igarapé-Miri } \\
56 \text { - Cumaru do }\end{array}$ & Barata & $\begin{array}{l}113 \text { - Pacajá } \\
114 \text { - Novo }\end{array}$ & $\begin{array}{l}142 \text { - Mãe do Rio } \\
143 \text { - Garrafão do }\end{array}$ \\
\hline $\begin{array}{l}27 \text { - Portel } \\
28 \text { - São Sebastião da }\end{array}$ & $\begin{array}{l}\text { Norte } \\
57 \text { - Santa Cruz }\end{array}$ & 85 - Inhangapi & Repartimento & Norte \\
\hline B.V. & do Arari & $\begin{array}{l}86 \text { - Baião } \\
87 \text { - Floresta do }\end{array}$ & 115 - Capitão Poço & \\
\hline 29 - Trairão & 58 - Uruará & A. & 116 - Itupiranga & \\
\hline
\end{tabular}

Published on: February, 12, 2020.

DOI: 10.5380/dma.v51i0.71685 
Erratum to: The impact of decentralization policies: the environmental performance applied to municipalities of the Amazon

Errata para: $O$ impacto de políticas descentralizadas: o desempenho ambiental aplicado a municípios da Amazônia

Benedito Evandro Barros da SILVA ${ }^{1,2 *}$, Claudia AZEVEDO-RAMOS ${ }^{3}$, Hilder André Bezerra FARIAS ${ }^{4}$

${ }^{1}$ Programa de Pós-Graduação em Desenvolvimento Sustentável dos Trópicos Úmidos, Universidade Federal do Pará (UFPA), Belém, PA, Brasil.

${ }^{2}$ Secretaria de Estado de Meio Ambiente do Pará (SEMAS/PA), Belém, PA, Brasil.

${ }^{3}$ Núcleo de Altos Estudos da Amazônia (NAEA), Universidade Federal do Pará (UFPA), Belém, PA, Brasil.

${ }^{4}$ Departamento de Economia, Universidade Federal do Pará (UFPA), Belém, PA, Brasil.

*E-mail of contact: evandroourem@yahoo.com.br

Article received on September 22, 2018, final version accepted on May 23, 2019, published on August 2019. 
The original article can be found online at:

http://dx.doi.org/10.5380/dma.v51i0.61705

References have been corrected, as follows:

Andersen, L. E.; Reis, E. J. Deforestation, development, and government policy in the Brazilian Amazon: an econometric analysis. Discussion Paper 69. Institute for Applied Economic Research - IPEA, 2015. Available at: http://repositorio.ipea.gov.br/bitstream/11058/4832/1/DiscussionPaper_69.p df. Accessed in: nov. 2017.

Andersson, K.; Gibson, C.; Lehoucq., F. Municipal politics and forest governance: comparative analysis of decentralization in Bolivia and Guatemala. World Development, 34(3), 576-95, $2006 . \quad$ doi: 10.1016/j.worlddev.2005.08.009

Andersson, K.; Laerhoven, F. V. From local strongman to facilitator: institutional incentives for participatory municipal governance in Latin America. Comparative Political Studies, 40(7), 1085-1111, 2007. doi: 10.1177/0010414006288977

Azevedo, A. A.; Rajão, R. L.; Costa, M.; Stabeli, M. C. C.; Macedo, M. N.; Dos Reis, T. N. P.; Alencar A.; Soares-Filho, B.; Pacheco, R. Limits of Brazil's Forest Code as a means to end illegal deforestation. PNAS, 114(29), 7653-7658. 2017. doi: 10.1073/pnas.1604768114

BACEN - Banco Central do Brasil. Crédito Rural. Ano base 2009 e 2013. 2017. Available at: http://www.bcb.gov.br/pt-br/\#!/n/CREDRURAL. Accessed in: May. 2017. 
Barona, E.; Ramankutty, N.; Hyman, G.; Coomes, O. T. The role of pasture and soybean in deforestation of the Brazilian Amazon. Environmental Research Letters, 5, 024002, 2010. doi: 10.1088/1748-9326/5/2/024002/meta

Bomfim, S. L. Índice de clima econômico para concessões florestais. $\mathrm{PhD}$ thesis. Universidade de Brasília (UNB), 2014. Available at: http://repositorio.unb.br/handle/10482/17230. Accessed in: Aug. 2017.

Celentano, D.; Veríssimo, A. O Avanço da Fronteira na Amazônia: do boom ao colapso. O Estado da Amazônia - Indicadores, 48. Belém: Imazon, 2007.

Coleman, E. A.; Fleischman, F. D. Comparing Forest Decentralization and Local Institutional Change in Bolivia, Kenya, Mexico, and Uganda. World Development, 40(4), 836-849, 2012. doi: 10.1016/j.worlddev.2011.09.008

Costello, A. B.; Osborne J. W. Best practices in exploratory factor analysis: Four recommendations for getting the most from your analysis. Practical assessment, research \& evaluation. 2005. Available at: http://pareonline.net/getvn.asp? $\mathrm{v}=10 \& \mathrm{n}=7$

De Lima, I. B.; Buszynski, L. Local environmental governance, public policies and deforestation in Amazonia. Management of Environmental Quality: An International Journal, 22(3), 292-316, 2011. doi: $10.1108 / 14777831111122888$

Falleti, T. Decentralization and subnational politics in Latin America. Cambridge University Press, Cambridge, 2010.

Fapespa - Fundação Amazônia de Amparo a Estudos e Pesquisas. (2014) Estatística Municipal do Pará 2014. Available at: $<$ http://www.fapespa.pa.gov.br/produto $>$. Accessed in: May. 2017.

Fapespa - Fundação Amazônia de Amparo a Estudos e Pesquisas. Anuário Estatístico do Pará 2015, 2015. Available at: $<$ http://www.fapespa.pa.gov.br/anuario_estatistico> Accessed in: May. 2017. 
FIRJAN - Índice FIRJAN de Desenvolvimento Municipal. Federação das Indústrias do Estado do Rio de Janeiro. 2015. Available at: $<$ http://www.firjan.com.br/ifdm/downloads/>. Accessed in: Oct. 2017.

Forgy, E.W. Cluster analysis of multivariate data: efficiency versus interpretability of classifications. Biometrics, 21,768-769, 1965.

Galbadón, A. J. La descentralización de la gestón ambiental en América Latina. Reforma y Democracia, 45,1-77, 2009.

Garcia, E.; Ramos Filho.; F. S. V; Mallmann, G. M; Fonseca, F. Costs, benefits and challenges of sustainable livestock intensification in a major deforestation frontier in the Brazilian Amazon. Sustainability, 9(1), 158, 2017. doi: $10.3390 /$ su9010158

Gibson, C.; Lehoucq, F. The local politics of decentralized environmental policy in Guatemala. Journal of Environment and Development, 12(1), 2849, 2003. doi: $10.1177 / 1070496502250437$

Guedes, G.; Costa, S.; Brondízio, E. Revisiting the hierarchy of urban areas in the Brazilian Amazon: a multilevel approach. Population and Environment, 30(4-5), 159-192, 2009.

Hair, J.; Black, W.; Babin, B.; Anderson, R.; Tatham, R. Multivariate data analysis (6th ed.). Pearson Prentice Hall. Uppersaddle River, N.J, 2006.

Hartigan, J. A. Clustering algorithms. John Willey and Sons. New York, NY, 1975.

Hecht, S. B. The Logic of Livestock and Deforestation in Amazonia. BioScience, 43(10), 687-695, 1993. doi: 10.2307/1312340

IBGE - Instituto Brasileiro de Geografia e Estatística. Indicadores de desenvolvimento sustentável. 2015. Available at: $<$ https://ww2.ibge.gov.br/home/geociencias/recursosnaturais/ids/default_20 15.shtm> Accessed in: Jan. 2017. 
IBGE - Instituto Brasileiro de Geografia e Estatística. SIDRA. 2017a. Available at: <http://www.sidra.ibge.gov.br>. Accessed in: Sept. 2017.

IBGE - Instituto Brasileiro de Geografia e Estatística. Pesquisa de Informações Básicas Municipais. 2017b. Available at: $<$ https://ww2.ibge.gov.br/home/estatistica/economia/perfilmunic/defaulttab1 _perfil.shtm> Accessed in: Feb. 2017.

IBGE - Instituto Brasileiro de Geografia e Estatística. Taxa de crescimento populacional. 2017c. Available at: <ftp://ftp.ibge.gov.br $>$ Accessed in: Feb. 2017.

IBGE - Instituto Brasileiro de Geografia e Estatística. IBGE Cidades, 2017d. Available at: <https://cidades.ibge.gov.br/> Accessed in: Dec. 2017.

INPE - Instituto Nacional de Pesquisas Espaciais. DEGRAD - Mapeamento da Degradação Florestal na Amazônia Brasileira. 2017b. Available at: $<$ http://www.obt.inpe.br/degrad//>. Accessed in: August 2017.

INPE - Instituto Nacional de Pesquisas Espaciais. PRODES - Sistema de Monitoramento do Desmatamento na Amazônia Legal. 2017a. Available at: $<$ http://www.dpi.inpe.br/prodesdigital/prodes.php> Accessed in: Aug. 2017.

INPE - Instituto Nacional de Pesquisas Espaciais. Projeto Terraclass. 2017c. Available at: $<$ http://www.inpe.br/cra/projetos_pesquisas/dados_terraclass.php>. Accessed in: Aug. 2017.

IPS Amazônia - Índice de Progresso Social na Amazônia Brasileira. 2014. Belém: Imazon e Social Progress Imperative. Available at: $<\mathrm{http}: / / \mathrm{www}$.ipsamazonia.org.br/\#aspects $\% 5 \mathrm{~B} \% 5 \mathrm{D}=1$ \&aspects $\% 5 \mathrm{~B} \% 5 \mathrm{D}=2$ \&aspects $\% 5 \mathrm{~B} \% 5 \mathrm{D}=7 \&$ aspects $\% 5 \mathrm{~B} \% 5 \mathrm{D}=12 \&$ map-view $=$ city\&maptype $=$ performance $\&$ active-cat $=1 \&$ page $=1 \&$ tab $=$ map $>$. Accessed in: Jun. 2018. 
Johnson, R. A.; Wichern, D. W. Applied multivariate statistical analysis. Prentice-Hall. Upper Saddle River, NJ, 2015.

Kaimowitz, D.; Mertens, B.; Wunder, S.; Pacheco, P. Hamburger connection fuels Amazon destruction. Center for International Forestry Research, 2004. Available at: $<$ http://www.cifor.cgiar.org/publications/pdf_files/media/Amazon.pdf $>$. Accessed in: Sept. 2017.

Larsen, P. B. Municipal environmental governance in the Peruvian Amazon: A case study in local matters of (in) significance. Management of Environmental Quality: An International Journal, 22(3),374-385, 2011. doi: $10.1108 / 14777831111122932$

Lloyd, S. P. Least squares quantization in PCM. IEEE Transactions on Information Theory. $1982 . \quad$ Available at: $<$ http://ieeexplore.ieee.org/document/1056489/> Accessed in: Nov. 2017.

Meijering, E. A chronology of interpolation: from ancient astronomy to modern signal and image processing. Proceedings of the IEEE, 90(3), 319$342,2002$.

MMA - Ministério do Meio Ambiente. Lista de Municípios Prioritários da Amazônia. 2013 Available at: $<\mathrm{http}$ ://www.mma.gov.br/images/arquivos/florestas/controle_e_prevencao/2 014/lista_\%20municipios_\%20prioritarios_07.08.pdf >. Accessed in: Sept. 2017.

Mori, K.; Christodoulou, A. Review of sustainability indices and indicators: Towards a new city sustainability index (CSI). Environmental Impact Assessment Review, 32, 94-106, 2012. doi: 10.1016/j.eiar.2012.06.001

Moutinho, P.; Guerra, R.; Azevedo-Ramos, C. Achieving zero deforestation in the Brazilian Amazon: what is missing? Elementa: Science of the Anthropocene, 2016. doi: 10.12952/journal.elementa.000125 
MS - Ministério da Saúde. DataSus - Sistema de Informações sobre Mortalidade, 2015.

Available

at:

$<$ http://tabnet.datasus.gov.br/cgi/deftohtm.exe?sim/cnv/pevita10PA.def $>$ Accessed in: Febr. 2017.

Nepstad, D.; McGrath, D.; Stickler, C.; Alencar, A.; Azevedo, A.; Swette, B.; Bezerra, T.; DiGiano, M.; Shimada, J.; Motta, R. S. da.; Armijo, E.; Castello, L.; Brando, P.; Hansen, M. C.; McGrath-Horn, M.; Carvalho, O.; Hess, L. Slowing Amazon deforestation through public policy and interventions in beef and soy supply chains. Science, 344(6188), 118-123, 2014. doi: $10.1126 /$ science. 1248525

Nepstad, D.; Veríssimo, A.; Alencar, A.; Nobre, C.; Lima, E.; Lefebvre, P.; Schlesinger, P.; Potter, C.; Moutinho, P.; Mendoza, E.; Cochrane, M.; Brooks, V. Large-scale impoverishment of Amazonian forests by logging and fire. Nature, 398, 505-508, 1999.

Nicole, A. G.; Tronchin D. M. R. Indicadores para avaliação do acesso vascular de usuários em hemodiálise. Revista da Escola de Enfermagem da USP, 45(1), 206-214, 2011. doi: 10.1590/S0080-62342011000100029

Persha, L.; Andersson, K. Elite capture risk and mitigation in decentralized forest governance regimes. Global Environmental Change, 24, 265-276, 2014.

PMV - Programa Municípios Verdes. Atividades e Resultados 2014/2015. Governo do Estado do Pará, 2016. Available at: $<$ http://www.municipiosverdes.pa.gov.br/relatorios/seleciona_tipo $>$ Accessed in: Jun. 2017.

Schmitt, J.; Scardua, F. P. The environmental decentralization and the enforcement of Amazon deforestation. Revista de Administração Pública, 49,1121-1142, 2015. doi: 10.1590/0034-7612131456 
SEMAS - Secretaria de Estado de Meio Ambiente e Sustentabilidade. Cadastro Ambiental Rural (2009 and 2015, Pará. Brazil). 2017b. Available at: <http://car.semas.pa.gov.br/\#/>. Accessed in: Nov. 2017.

SEMAS - Secretaria de Estado de Meio Ambiente e Sustentabilidade. Relação de Municípios que possuem capacidade para exercer a gestão ambiental de forma plena e/ou parcial. Pará. Brazil. (2017a). Available at: $<$ https://www.semas.pa.gov.br/wp-content/uploads/2017/12/municipiosgestao-ambiental-21-12-17.pdf $>$ Accessed in: Aug. 2017.

Silva, B. E. B. da.; Azevedo-Ramos, C. Evolução da Descentralização da Gestão Ambiental Municipal no Estado do Pará. In: Pezzuti J, AzevedoRamos C. (Eds.). Desafios Amazônicos. Série Desenvolvimento e Sustentabilidade. NAEA editora. Belém, Pará. Brazil. Pp 261-296, 2016.

Singh, R. K.; Murty, H. R.; Gupta, S. K.; Dikshit, A. K. An overview of sustainability assessment methodologies. Ecological Indicators, 9(2), 189212, 2009.

Thompson, B. Exploratory and confirmatory factor analysis: Understanding concepts and applications. American Psychological Association, Washington, DC, 2004.

Viana, C.; Coudel, E.; Barlow, J.; Ferreira, J. N.; Gardner, T. A.; Parry, L. How does hybrid governance emerge? Role of the elite in building a green municipality in the Eastern Brazilian Amazon. Environmental Policy and Governance, 26(5), 337-350, 2016.

Wood, C. H.; Perz, S. G. Population and land-use changes in the Brazilian Amazon. In: Ramphal, S. D.; Sinding S. W. (Eds.). Population growth and environmental issues. Praeger. Westport, Connecticut. Pp. 95-108, 1996.

Zarin, D. J.; Harris, N. L.; Baccini, A.; Aksenov, D.; Hansen, M. C.; AzevedoRamos, C.; Azevedo, T.; Margono, B. A.; Alencar, A. C.; Gabris, C.; Allegretti, A.; Potapov, P.; Farina, M.; Walker, W.S.; Shevade, V.S.; Loboda, 
T.V.; Turubanova, S.; Tyukavina, A. Can Carbon emissions from tropical deforestation drop by $50 \%$ in 5 years? Global Change Biology, 22(4), 13361347, 2016. doi: $10.1111 / \mathrm{gcb} .13153$

Published on: September, 22, 2020.

DOI: $10.5380 /$ dma.v51i0.76698 